\title{
The price of policy risk - Empirical insights from choice experiments with European photovoltaic project developers
}

\author{
Sonja Lüthi ${ }^{*}$, Rolf Wüstenhagen \\ Institute for Economy and the Environment (IWÖ-HSG), University of St. Gallen, Tigerbergstr. 2, CH-9000 St. Gallen, Switzerland
}

\section{A R T I C L E I N F O}

\section{Article history:}

Received 26 March 2010

Received in revised form 8 June 2011

Accepted 12 August 2011

Available online 22 August 2011

\section{Jel classification: \\ Q42 \\ Q48 \\ Q55 \\ L98 \\ D22 \\ D81}

\section{Keywords:}

Adaptive conjoint analysis

Choice experiment

Feed-in tariff

Photovoltaic

Policy design

\begin{abstract}
A B S T R A C T
Managing the transition to a renewable energy future is an important policy priority in many countries. Solar photovoltaic (PV) technology is expected to make an essential contribution, but due to relatively high cost, its growth to date has been largely driven by public policy, notably feed-in tariffs. Feed-in tariffs have been implemented in various countries, but with widely differing outcomes in terms of installed PV capacity. Previous research indicates that the level of policy risk may be an important driver for differences in renewable energy policy effectiveness. This paper suggests that project developers who make a decision between PV investment opportunities in different countries carefully weigh feed-in tariff-induced returns against a set of policy risks, and choose the country with the most favorable risk-return profile. This model is empirically tested by a stated preference survey among European PV project developers, consisting of 1575 choice decisions by 63 investors. The findings demonstrate that risk matters in PV policy design, and that a "price tag" can be attached to specific policy risks, such as the duration of administrative processes or uncertainty induced by an approaching capacity cap. Governments can build on these empirical results to design policies that will be effective in attracting private PV investment, while at the same time maintaining efficiency by providing an adequate compensation for policy risk.
\end{abstract}

(c) 2011 Elsevier B.V. All rights reserved.

\section{Introduction}

In order to address the twin challenges of climate change and energy security, governments around the world are increasingly adopting policies to increase the share of renewable energy. While the overall share of renewable energy in global electric power supply is still low, there is significant growth in some subsectors. For example, $39 \%$ of all newly installed power generation capacity in Europe in 2009 was based on wind energy, and the wind turbine industry has grown by $29 \%$ per annum over the past decade. Solar photovoltaic (PV), while starting from lower levels, has seen even higher growth rates from 2004 to 2008. While the cost of wind energy has reached grid parity in good locations and hence it is sometimes the most competitive source of electricity, the cost of solar PV is still significantly higher than that of conventional electricity sources. Therefore, growth of the PV market has been largely driven by policy incentives.

One of the most widely adopted policy instruments to support PV is the feed-in tariff scheme, first introduced in Germany's renewable

\footnotetext{
* Corresponding author.

E-mail addresses: sonja.luethi@unisg.ch (S. Lüthi), rolf.wuestenhagen@unisg.ch (R. Wüstenhagen).

URL: http://goodenergies.iwoe.unisg.ch (R. Wüstenhagen).
}

energy legislation in 1991. More recently, feed-in tariffs have been enacted in a large number of countries, partly as a result of the apparent effectiveness in increasing renewable energy capacity in Germany. As this policy has spread across countries, however, an important empirical puzzle emerged: seemingly similar policy frameworks have led to significantly different outcomes in different countries. For example, Germany, Spain and Greece all offered feed-in tariffs of approximately 45 $\mathrm{ct} / \mathrm{kWh}$ for solar electricity generators in 2007 , but newly installed capacities in that year ranged from 1.135 MW in Germany to $505 \mathrm{MW}$ in Spain to just 2 MW in Greece (Sarasin, 2009).

An increasing body of research tries to shed light on the reasons behind such differences in energy policy effectiveness. While early contributions in this strand of research have highlighted the importance of sufficiently high support levels and the long-term stability of policy frameworks, more recent work is drawing attention to the importance of policy risk. There seems to be an emerging consensus that an important feature of effective policies is that they succeed in reducing risk for investors. However, empirical evidence to identify the most important risk factors is still limited, and valid results on the relationship between specific attributes of policy risk and investment outcome are difficult to find because there are only a small number of cases where significant levels of new renewable energy capacity have been achieved. 
Our research addresses these challenges by moving from an ex post analysis of revealed preferences to an ex ante analysis of stated preferences of key decision-makers in the solar market. We conducted a survey among European PV project developers using choice experiments. This methodology is widely used in marketing research and has recently gained some popularity in the energy and resource economics literature, but, to the best of our knowledge, the current paper is the first to apply this methodology to the analysis of investment choices based on renewable energy policy frameworks. As a result, our research allows the empirical measurement of the "price of policy risk", i.e. project developers' willingness-to-accept (WTA) certain policy risks. This allows policymakers to make a more conscious trade-off between the level of feedin tariff offered and the reduction of important policy risks for project developers, ultimately leading to more efficient policy frameworks.

The structure of the paper is as follows. The next section reviews existing literature on renewable energy policy effectiveness and the role of policy risk in renewable energy investment. Section 3 describes our experimental design, and the estimation model is specified in Section 4 . Section 5 outlines the data and sample; Section 6 presents and discusses the empirical results. Section 7 concludes with implications for policy-makers and suggestions for further research.

\section{Literature review}

Investigating the efficiency and effectiveness of renewable energy policies has become a popular theme among energy economics researchers. A large number of country-level case studies have been carried out across different geographies, renewable energy technologies and policy instruments (Breukers and Wolsink, 2007; Jacobsson and Lauber, 2006; Lipp, 2007; Toke et al., 2008; Wüstenhagen and Bilharz, 2006). While some early works pointed to a potentially higher efficiency of trading schemes such as renewable portfolio standards, quota systems and green certificates (Kühn, 1999; Lenz and Pfaffenberger, 1999), feed-in tariffs - especially in the case of Germany - soon built a reputation for being more effective in increasing new renewable energy capacity (Rickerson and Grace, 2007). As more countries introduced renewable energy policy schemes, an additional insight emerged, namely that the answer to the question of which energy policy is most efficient and most effective may actually be that "it depends". For example, as much as trading schemes appear to be an elegant way of minimizing cost to society in economic models (Palmer and Burtraw, 2005), their implementation in real life suffers from limitations including market power and transaction cost (Amundsen and Mortensen, 2001; Bergek and Jacobsson, 2010; Jacobsson et al., 2009; Jensen and Skytte, 2002; Menanteau et al., 2003; Verbruggen, 2004; Verhaegen et al., 2009). A similar argument can be made about carbon pricing: While in simple economic models, full internalization of external cost with sufficiently high carbon prices would seem like a "first-best" solution, applied climate policy needs to deal with market imperfections such as market power or low levels of R\&D investment. Specific renewable energy policies, if properly designed, may help to overcome such imperfections (Böhringer et al. 2009, IPCC 2011). Also, implementation of appropriate carbon prices has remained a significant political acceptance challenge to date. Conversely, feed-in tariffs seem to work well in Germany, but are sometimes criticized for their relatively high cost, especially in the case of PV (Frondel et al., 2008), which may also be related to the market power of incumbents (Ropenus and Jensen, 2009), and their implementation in other countries showed a striking variety of outcomes (Campoccia et al., 2009; Lüthi, 2010; Rowlands, 2005). Recent analyses, on the other hand, demonstrate that well-designed feed-in tariffs might actually outperform trading schemes in both efficiency and effectiveness (Butler and Neuhoff, 2008; OECD/IEA, 2008; Ragwitz et al., 2007). One way of summarizing the state of debate is that for many renewable energy policies, the devil is actually in the details (Ringel, 2006), and it is a fine-tuned set of ingredients of a country's policy mix rather than any archetype of a "price-driven" or "quantity-driven" policy instrument that results in efficient and effective deployment of renewables (Dinica, 2006; Menanteau et al., 2003). Those ingredients that policy-makers must get right beyond the ideal choice of policy type include a series of so-called non-economic barriers to renewable energy implementation (OECD/IEA, 2008), such as planning restrictions (Nadaï, 2007) and connection charges (Butler and Neuhoff, 2008).

A recent stream of research has highlighted the importance of risk in policy design. Variations in policy outcomes can thus be traced back to variations in the level of risk implied by different policies. This has been offered as an explanation for why feed-in tariffs have resulted in higher levels of new renewable energy capacity than green certificate systems (Mitchell et al., 2006). Lowering risk is a particularly important feature of policy design because of its impact on financing cost for renewable energy projects (De Jager and Rathmann, 2008; Langniss, 1999; Wiser and Pickle, 1998). Policies that effectively reduce (perceived) risk for investors are more likely to result in large-scale deployment of renewable energy. There have been various calls for including an investor or project developer perspective in the analysis of energy policies (e.g., Birol, 2003; Dinica, 2006; Gross et al., 2010; Wüstenhagen and Menichetti, 2012), and yet there is relatively little empirical evidence so far about how policies and their risk are actually perceived by investors and project developers (Bürer and Wüstenhagen, 2009; Masini and Menichetti, 2012). The analysis presented here is an attempt to contribute to this emerging stream of research, and at the same time to address two limitations of previous research that remain largely unaddressed: first, much of the previous research trying to assess the impact of risk on renewable energy policy effectiveness is based on country-level case studies, which inherently limits the analysis to aggregate measures of risk in a given country, rather than leading to specific insights about the importance of individual risk components. Second, the empirical literature has largely relied on ex post analyses of revealed preferences, i.e., realized investments. This may be fine in slow-moving markets where long time series are available, but creates a problem in the dynamic renewable energy market in that it inherently limits analysis to those few countries that already offer some history in deploying renewables, and in that the policy recommendations based on such ex post analyses might systematically come too late. What we suggest is to move towards choice experiments with project developers as a way to get real-time information about how policy risks affect today's investment, and hence tomorrow's installed capacity (Usher, 2008).

\section{Experimental design}

\subsection{Method}

The objective of this study is to investigate the influence of the most important attributes of solar energy policies on the decision of a PV project developer to invest in a given country, in order to empirically measure their willingness-to-accept specific policy risks. As a result, we aim at providing recommendations for the design of effective PV policies. Investigating the influence of policy attributes on project developers' decisions can be done through either revealed or stated preference approaches. Revealed preference approaches are based on an ex post analysis of actual investment decisions. An important requirement thus is that sufficient time-series data (or enough countries to work with cross-sectional data) are available. In the case of international solar energy investments, we are addressing a phenomenon that has only emerged in the last 2-3 years, and hence only a limited amount of country-level data would be available for analysis. Stated preference approaches, on the other hand, can overcome some of the challenges of revealed preference methods. By confronting respondents (in this case, project developers) with hypothetical, but realistic, choice situations, decision behavior can be studied in real time, or even before it actually occurs in the field. Consequently, stated preference approaches have become popular in marketing research with regard to understanding consumer preferences for 
newly developed products (Green and Srinivasan, 1990). One particularly popular method is choice experiments, also referred to as conjoint analysis in the marketing literature. Conjoint analysis was initiated by mathematical psychologists (Anderson, 1970; Kruskal, 1965; Luce and Turkey, 1964) and was introduced in marketing research in the early 1970s (Green and Srinivasan, 1990; Orme, 2007b). Over time, the use of choice experiments and conjoint analysis has spread from its origin in marketing research to a wide array of research communities such as entrepreneurship (Lohrke et al., 2010), environmental economics (Ahn et al., 2008; Boxall et al., 1996; Burkhalter et al., 2009; Casey et al., 2008; Chattopadhyay, 2009; Farber and Griner, 2000; Glenn et al., 2010; Roe et al., 1996), transportation economics (Hensher, 1994; Hensher, 2010; Train and Wilson, 2008) and energy efficiency research (Banfi et al., 2008; Moxnes, 2004; Poortinga et al., 2003).

The methodological approach of this study is novel in that it uses choice experiments to investigate PV project developer choices among policy frameworks. Hence, we argue that a project developer's choice among different opportunities to develop international solar energy projects is essentially similar to the decision of a customer to buy a new product. In particular, we assume that these investment decisions comply with the fundamental assumptions underlying conjoint analysis (Lancaster, 1966), namely that project developer will choose from a given choice set the alternative that maximizes their utility, and that this utility can be described as the sum of part-worth utilities of the alternatives' attributes. Utility maximization theory has been successfully applied to the analysis of investor preferences or financial choices in other studies. Venditti et al. (2007) for example, evaluated complex financial deals using adaptive conjoint analysis (ACA). Instead of spending many hours evaluating financial deals and presenting the details of those deals to a committee of three individuals, they developed a decision model approach to evaluate deal approval likelihood for structured finance products. The market simulator based on three respondents was found to be highly predictive of whether deals were approved or rejected in the months following the surveys (accuracy of about $80 \%$ ). The study demonstrated that effective conjoint models (to profile very small populations) can be built using small sample sizes and that conjoint analysis can provide good data for implementing sophisticated decision support tools in non-traditional contexts. Wilcox (1999) conveyed how choice-based conjoint analysis can be used to learn how retail investors evaluate key attributes of a mutual fund. The weight investors give to fees charged by a fund can be used by fund managers to design the fee structures that will maximize utility for both the client and the fund manager. Clark-Murphy and Soutar (2004) use a conjoint analysis approach to investigate the attributes that influence individual investors when they make a decision to buy shares.

A number of different variations of conjoint analysis are available (Backhaus et al., 2006; Orme, 2007b; Priem and Harrison, 1994). For example, full-profile methods such as choice-based conjoint analysis (CBC), where respondents make trade-offs between all attributes of the choice alternatives simultaneously, can be distinguished from partial profile methods such as adaptive conjoint analysis (ACA), where respondents are first asked to rank the importance of attributes followed by choice tasks that gradually build up complexity (Sawtooth Software, 2007). We decided to do an ACA survey, which is preferable over $\mathrm{CBC}$ in the case of smaller samples and in rather explorative settings where the key attributes of the choice situation are not obvious to the researcher ex ante (Orme, 2010a).

The next section (Section 3.2) will provide more detail about how we selected and operationalized the attributes of the choice experiments. Section 4 will specify the foundations of conjoint analysis and the model applied in this study.

\subsection{Selection of attributes and levels}

A qualitative pre-study was carried out to learn which attributes influence the location decision of a PV project developer. For this reason, eight expert interviews (Flick, 1995) were conducted with PV project developers and other solar or project development specialists. The market professionals were asked to recount their location decision process and to explain the different influencing factors. In this way, the roles of host country characteristics as determinants in investment choice patterns, especially in regard to policy attributes, were reviewed. Based on this qualitative pre-study, an online questionnaire consisting of two parts was compiled: the ACA experiment about the importance of PV policy attributes, and questions to obtain background information about the experience and activities of the project developers and their firms.

The interviews confirmed the prominent role of policy conditions among the factors influencing a PV project investment decision. These political conditions include the availability of financial incentive schemes, the application procedure, policy targets for the future share of solar energy and the stability of support policies. Besides political conditions, legal, economic and climatic conditions were also mentioned by the interviewed experts. The legal conditions mentioned included mandatory interconnection standards, legal security and the enforcement of private property rights. Economic conditions included currency risk and electricity wholesale price. The relevant climatic condition is obviously the level of solar radiation, which directly influences a project's profitability. To reduce the number of attributes to a manageable number, we decided to exclude factors from further analysis that were relatively homogeneous among the countries studied. For example, legal security can be described as sufficiently high in the European countries we investigated, as opposed to some developing countries, which were not the focus of this study. Also, currency risk played a minor role because most of the countries considered were part of the European single currency area. As for solar resources, we decided to keep this factor constant by asking respondents to assume a solar radiation of $1500 \mathrm{kWh} / \mathrm{m}^{2}$ a. This is a realistic value for a number of the Southern European countries that attract a substantial part of the investments made by our target population of PV project developers. Apart from solar radiation, a second factor that was kept constant was the type and size of the assumed project: a greenfield solar plant with an installed capacity of $500 \mathrm{~kW}_{\mathrm{p}}$.

Based on the qualitative pre-study, five attributes were finally chosen for the ACA experiment, which reflected key factors determining the level of risk and return for investors: 'Level of tariff, 'Duration of tariff, 'Existence of a cap' (or the time until the cap is reached), 'Duration of the administrative process' and 'Policy instability' (operationalized as the number of significant unexpected policy changes in the last 5 years). Table 1 shows a short description of each attribute, together with the levels presented in the survey.

\subsection{Questionnaire design}

The computer-based ACA survey was designed with Sawtooth, which is the standard software solution for the design and analysis of conjoint experiments in marketing research (Sawtooth Software, 2007). At the beginning, the respondents are asked to compare attribute pairs (cf. Fig. 1). Each question showed descriptions of hypothetical political framework conditions for two countries composed of different levels including two attributes at the beginning, then three, and then four. Assuming that the conditions were identical in all other ways, respondents should indicate which country they would preferably choose as the next project location. Rather than being asked to simply choose one or another, project developers could provide differentiated answers on a nine point scale ranging from "strongly prefer left" to "strongly prefer right". The number of "Paired-Comparison" questions to be asked is equal to $3 *(\mathrm{~N}-\mathrm{n}-1)-\mathrm{N}$, where $\mathrm{N}$ is the total number of levels and $\mathrm{n}$ is the total number of attributes, i.e. $3 *(19-5-1)-19=20$.

In the last section, the questionnaire included a series of "Calibrating Concepts" where the product alternatives are described by levels of all attributes (cf. Fig. 2). These concepts are calculated individually for each respondent based on his previous answers. The respondent is 
Table 1

Attributes and attribute levels used in the ACA experiment.

\begin{tabular}{|c|c|c|c|c|c|c|}
\hline \multirow{2}{*}{$\begin{array}{l}\text { Attributes } \\
\text { Level of Feed-in } \\
\text { Tariff [ct/kWh] }\end{array}$} & \multirow{2}{*}{$\begin{array}{l}\text { Description } \\
\text { The amount paid per } \\
\text { kWh fed into the grid. }\end{array}$} & \multicolumn{5}{|c|}{ Attribute levels } \\
\hline & & 31 & 35 & 38 & 41 & 45 \\
\hline $\begin{array}{l}\text { Duration of Feed-in } \\
\text { Tariff [years] }\end{array}$ & $\begin{array}{l}\text { Number of years for } \\
\text { which the feed-in tariff } \\
\text { is guaranteed. }\end{array}$ & 15 & 20 & 25 & & \\
\hline $\begin{array}{l}\text { Existence of a } \\
\text { cap }\end{array}$ & $\begin{array}{l}\text { Presence of a market } \\
\text { cap limiting the } \\
\text { promoted PV capacity, } \\
\text { and if a cap exists, the } \\
\text { predicted time until it } \\
\text { will be reached. }\end{array}$ & $\begin{array}{l}\text { No } \\
\text { cap }\end{array}$ & $\begin{array}{l}\text { Cap } \\
\text { reached } \\
\text { in } \\
4 \text { years }\end{array}$ & $\begin{array}{l}\text { Cap } \\
\text { reached } \\
\text { in } \\
1 \text { year }\end{array}$ & & \\
\hline $\begin{array}{l}\text { Duration of the } \\
\text { administrative } \\
\text { process [months] }\end{array}$ & $\begin{array}{l}\text { Predicted time from } \\
\text { the project submission } \\
\text { until all permits are } \\
\text { obtained. }\end{array}$ & $\begin{array}{l}1- \\
2\end{array}$ & $3-6$ & $7-12$ & $\begin{array}{l}13- \\
18\end{array}$ & $\begin{array}{l}19- \\
24\end{array}$ \\
\hline $\begin{array}{l}\text { Significant } \\
\text { unexpected } \\
\text { policy changes in } \\
\text { the last } 5 \text { years }\end{array}$ & $\begin{array}{l}\text { A change is considered } \\
\text { as significant if it leads } \\
\text { to more than } 15 \% \text { of } \\
\text { feed-in tariff reduction. }\end{array}$ & 0 & 1 & 3 & & \\
\hline
\end{tabular}

asked to indicate a "likelihood of choosing" between 0 and 100 about each. To assess the spread, the concept with the lowest estimated utility is presented first and then the one with the highest estimated utility.

\section{Model specification}

ACA is based on the discrete choice theory (Ben-Akiva and Lerman, 1985; Train, 2009) which follows the microeconomic consumer theory. Consumer theory analyzes the economic decisions, and especially the consumption decisions, of private households. It states that a consumption decision follows a cost-benefit comparison of the different product alternatives, and that the consumer chooses the product that maximizes his utility. Lancaster (1966) advanced this theory by indicating that products can be considered as bundles of attributes, and that the utility of a product is the sum of the part-worth utilities of its attributes. However, it is not possible to completely describe any product in terms of its attributes; there will always be some unknown or intangible characteristic which may also provide utility. As a result, the other underlying foundation of discrete choice theory and conjoint analysis is Random Utility Theory (Mansky, 1977), which allows the direct utility function to be broken down into observable (deterministic) and unobservable (stochastic) parts.

The present study does not evaluate the choices among products, but among policy frameworks, and thus transfers this concept to renewable energy investment. Analogous to a product, the policy framework of a country can be described as a bundle of attributes. As stated in the previous section, this study has chosen the level of return, plus a set of policy risks, as the main attributes determining project developers' choices. A utility maximizing PV project developer aims at developing a project in the country that provides the highest utility. As in the case of a choice among products, also when choosing among policy frameworks, there is an inevitable trade-off between the different attributes, and any attribute change influences the attractiveness of the respective country for the project developer. A higher level of return, for example, increases the utility and thus the attractiveness of a country whereas higher policy risks decrease the country's utility.

The utility of a policy framework $U$ can thus be described as:

$U=\sum_{i=1}^{m} u_{i}+e$

where $m$ are the different policy attributes, $u_{i}$ the part-worth utilities of the different attributes and $e$ the unknown or intangible characteristic.

The probability that a project developer $i$ chooses the policy framework $j$ from choice set $C_{t}$ is given by the following:

$P_{i j}=\operatorname{Pr}\left(U_{i j} \geq U_{i n} ; \forall j \neq n ; j, n \in C_{t}\right)$

where $U$ is the utility of the specific policy framework and $n$ are the alternative policy frameworks.

Part-worth measures the contribution of attribute levels to the overall utility of a product, i.e., the influence of a change of the respective variable on the developer's likelihood to develop a specific project. The average part-worth utilities are based on the individual part-worth utilities estimated with Linear regression model using Bayesian estimation method (Orme, 2007a; Rossi and Allenby, 2003) using Sawtooth Software Inc. programs (SSI Web, ACA/HB and SMRT; Sawtooth Software, 2007). The HB estimation model has become the standard estimation method for conjoint analysis (Lenk et al., 1996; Netzer et al., 2008; Rossi and Allenby, 2003). Individual utilities allow assessing heterogeneity among customer segments, which is more difficult with traditional conjoint approaches based on aggregated preferences measures (e.g., standard multinominal logit (MNL) (McFadden, 1986)).

The basic idea behind the use of $\mathrm{HB}$ is to recognize that each individual is a member of a group of more or less similar individuals, and that knowledge of the entire distribution of individuals' part-worth utilities can enhance estimation for each individual. Individuals are assumed to be distributed multi-normally, and HB estimates the mean vector and covariance matrix for that distribution. The HB model consists of two levels. At the upper level, respondents are considered as members of a population of similar individuals (Orme, 2010b). Their part-worth utilities are assumed to have a multivariate normal distribution described by a vector of means and a matrix of variances and covariances. At the lower level, each individual's part-worth utilities are calculated by a linear regression model according to the respondent's choices within the conjoint analysis experiment. Discrepancies between actual and predicted ratings are assumed to be distributed normally and independently of one another. With several thousands of iterations (for this study, 15,000 iterations were done), each respondent's utilities are adjusted

\section{Assuming all the political framework conditions being equal, which op tion would}

\section{you prefer?}

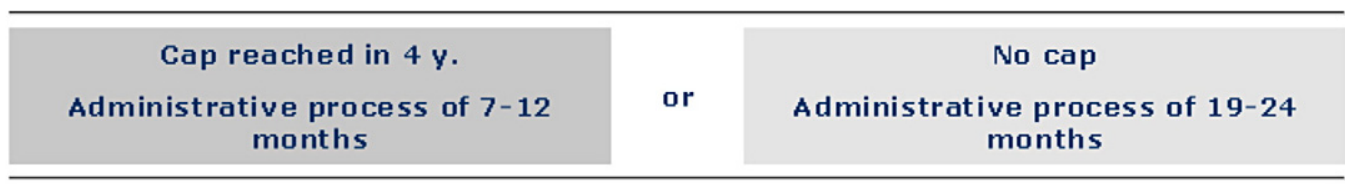

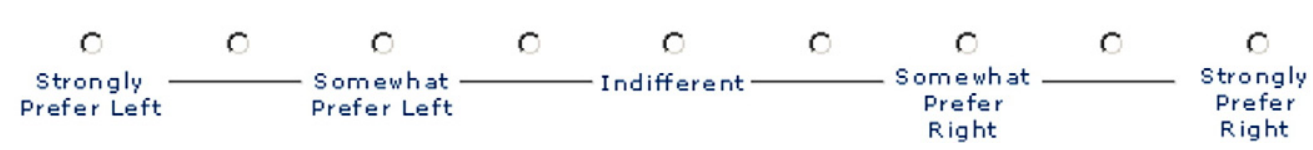

Fig. 1. Screenshot of a "Paired-Comparison" question. 


\section{How likely would you choose the country with these political framework conditions?}

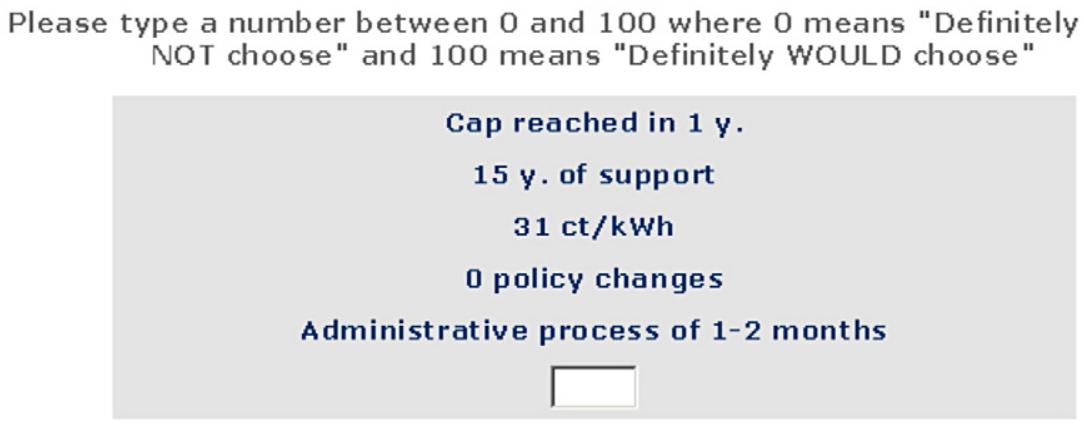

Fig. 2. Screenshot of a "Calibrating Concept" question.

so that they reflect the optimal mix of the individual respondent ratings and the sample averages (Howell, 2009).

The utilities are interval data, meaning they are scaled to an arbitrary additive constant to sum to 0 within each attribute. Therefore a negative part-worth value for a certain attribute level does not indicate that this attribute level is unattractive per se, but it shows that it is less preferred than other levels of the same attribute with a higher part-worth value.

The relative importance of each attribute can be estimated from the ACA data by considering how much difference each attribute could make in the overall utility of the product, i.e., between the highest and the lowest utility value of each attribute. That difference is the range in the attribute's utility values. The bigger the range is, the more a variation in the attribute can lead to a variation of the overall utility (Backhaus et al., 2006). The relative importance of each attribute is calculated using the formula (adapted from Clark-Murphy and Soutar (2004)):

$R_{l}[\%]=\frac{(\operatorname{Max} U-M i n U) i}{\sum(\operatorname{Max}-\operatorname{Min}) i} \times 100$

where $R I_{i}$ is the relative importance of attribute $i$; MaxU the maximum utility of attribute $i$; and $\operatorname{Min} U$ the minimum utility of attribute $i$.

The standard deviation of the individual part-worth utilities of level $l$ is calculated using the following formula:

$S D_{l}=\left[\frac{\sum_{i=1}^{n}\left(U_{l i}-U_{l}\right)^{2}}{n-1}\right]^{1 / 2}$

where $S D_{l}$ is the standard deviation of the part-worth utilities of level $l ; U_{l}$ the part-worth utility of the attribute level $l ; n$ the number of survey participants.

The standard deviations for individual-level estimates are a measure of heterogeneity and a measure of precision. If the individual-level utilities were given without error by each respondent, there would be differences between people, due to preference heterogeneity, and thus the standard deviation would fully reflect that. But, if the people actually had the same true preferences and our estimates for each individual involved error, then, the standard deviation would directly capture the error and there would be no heterogeneity. Typical conjoint designs have nearly equal precision for each level within the same attribute because each level appears an equal number of times and the levels are orthogonal to other attributes' levels. As a result, a higher standard deviation usually reflects a higher heterogeneity of preferences. At this point, it is important to note that the standard deviations can only be compared within the same attribute, but not between attributes, as the means can be very different; the larger the magnitude of the attribute's utility, the larger the standard deviations.
As the monetary variable feed-in tariff is included in the study, the marginal WTA certain policy risks can be derived using the formula (Orme, 2001)

$W T A_{l}\left[\frac{\mathrm{ct}}{\mathrm{kWh}}\right]=-1\left(U_{l}-\operatorname{Max}_{l}\right) \frac{\Delta F i T}{\operatorname{MaxFiTU}}$

where $W T A_{l}$ is the implicit WTA of the attribute level $l$; $U_{l}$ the partworth utility of the attribute level $l ; \operatorname{Max}_{l}$ the maximum partworth utility of the attribute in question; $\Delta F i T$ the difference of the level of feed-in tariff, i.e. $14 \mathrm{ct} / \mathrm{kWh}$; and MaxFiTU the maximum utility of the attribute "Level of tariff".

\section{Data and sample}

The results presented in this paper are based on a unique dataset collected through an online survey conducted in October-November 2008. The population of interest for the survey was European PV project developers which were engaged in or were considering undertaking PV projects abroad in other European countries. There is no universally agreed upon definition of a project developer and his business. In general we can define three main types of firms engaged in the project development business:

- Highly specialized, typically small, firms whose exclusive business focus is to develop renewable energy projects. Due to the lack of capital or financing, they often sell the project to later-stage investors during or after the development process.

- Vertically integrated, typically larger, firms, who plan, build, own and operate renewable energy projects. They are often customers of the first group.

- A wide range of others, for whom the development of renewable energy projects is an activity outside their core business. These include electric utilities, financial investors (including banks, pension funds and insurance companies), equipment suppliers and land or building owners. Depending on their focus and risk/return expectations, they get involved in various stages of project development.

Given the wide range of players and the emerging nature of this industry, it is hard to determine an exact number for the total size of this group. The European Photovoltaic Industry Association (EPIA) membership directory ${ }^{1}$ lists more than 240 companies on different parts of the value chain, including manufacturers of solar cells, modules, etc. There is no specific category "project development" in the EPIA membership directory. The German solar industry association, Bundesverband Solarindustrie (BSi), has 877 member firms, ${ }^{2}$

\footnotetext{
${ }^{1}$ http://www2.epia.org/New2009/Members_2009a.asp.

2 http://www.solarwirtschaft.de/.
} 
including not just PV firms, but also companies active in solar thermal energy. 109 of these firms are categorized as solar PV project developers. We assume that there may be some firms that are active in the market but not members of the industry association and others may not be properly categorized in the membership directory, so we estimate the total number of project developers in Germany to be 200. Only some of them are potential investors in international projects and hence the core group of interest for our study, resulting in a final estimate for the German of our target population of 150 . Based on industry magazines, conversations with industry experts and an analysis of market size by country, we assume that the number of European PV project developers who engage in cross-border investments in the typical project size assumed in the survey $(500 \mathrm{~kW})$ is smaller in other significant PV markets such as Italy, Spain and France than in Germany. Furthermore, there are a small number of international project developers in each of a variety of other European countries including Greece, Switzerland, Austria, Benelux, Czech Republic, UK, Portugal and Scandinavia. Consequently, we estimate the size of the total target population of our study to be in the range of 300-400 project developers.

Table 2 provides an overview of the size of the population and the market and provides evidence about the geographical distribution of respondents and their firms in the sample. We intended to reach a sample that represents the descriptive statistics and geographical distribution of the total population. This could be confirmed by PV industry experts (Paris, 2010).

The PV project developers were solicited to participate in the survey by phone and/or e-mail, at a solar industry fair, by means of an article on an industry-specific news website (www.solarserver.de) and its newsletter and by an insert in a solar industry journal. In total, 312 invitations were made to PV project developers (some developers received multiple invitations). One hundred thirty-five respondents logged on to the survey website and 63 questionnaires were completed. The response funnel is shown in Fig. 3. With 63 complete responses out of a total population of 340 project developers, the final conversion rate was $18.5 \%$. The relatively high drop-out rate may have been a result of the length of the ACA questionnaire, which took an average $20 \mathrm{~min}$ to complete - a significant time investment for a busy international manager. Each project developer completed 25 choice tasks, resulting in a final data set of 1575 choice decisions.

A detailed sample description can be found in the Appendix A. In terms of firm type, $30.2 \%$ of respondents indicated that their firm was a specialized (early-stage) project developer, while $50.8 \%$ were vertically integrated firms. The remaining $19.0 \%$ are others, including financial investors and utilities. Regarding the stage of activity in the project development cycle, 56\% of the respondents' companies are active in all stages of the project cycle, 33\% in the planning, $6 \%$ in the construction and $2 \%$ in the operation and maintenance phase.

The sample is about evenly split between experienced project developers ( 4 or more years of experience: $44.4 \%$ ) and those that are relatively new to the industry (up to 3 years of experience: 55.6\%). This illustrates the emerging nature of the PV industry, but also indicates that our sample includes a substantial portion of experienced professionals. In terms of the number of projects realized, $49.2 \%$ of the interviewed persons have been involved in 1-9 projects and $39.7 \%$ in 10 or more PV projects. Seven respondents (11.1\%) had considered investments, but not actually completed a project yet. Six project developers (9.5\%) have worked on more than 100 projects. One-third of the realized projects are smaller projects with an installed capacity of less than $100 \mathrm{~kW} ; 23.8 \%$ of the projects are between 100 and $500 \mathrm{~kW} ; 39.7 \%$ are between $500 \mathrm{~kW}$ and $10 \mathrm{MW}$; and 3.2\% are bigger than $10 \mathrm{MW}$. Taking a look at firm size, there is a relatively large share of small and medium-sized firms in our sample (77.8\% of firms have less than 100 employees), again reflecting the entrepreneurial character of this newly emerging industry.

Table 4 provides some information about the geographic distribution of our sample and gives evidence of the high degree of internationalization in the sector. In terms of country of origin, German project developers represent just under half of the sample (48.0\%), followed by developers from Spain (17.3\%), Italy (10.7\%) and several other countries. As for target countries for investments, $69.8 \%$ of the firms are active in Germany, $57.1 \%$ in Spain, $49.2 \%$ in Italy, $30.2 \%$ in Greece, $27.0 \%$ in France and $17.5 \%$ in Portugal. To ensure that our respondents were qualified to answer the choice tasks related to assessing policy frameworks, we also asked them about their familiarity with solar energy policies in those countries. The results suggest that (self-declared) policy knowledge of respondents is high, and corresponds well to the target countries they invest in: $77.8 \%$ of the interviewed PV project developers said they are familiar with the PV policy situation of Germany, 71.4\% of Spain, 58.7\% of Italy, 42.9\% of Greece, 36.5\% of France, and 19.0\% of Portugal.

\section{Results}

In the following, we report estimation results in three steps: relative importance of attributes, part-worth utilities and project developers' implicit willingness-to-accept certain policy risks.

\subsection{Relative importance of attributes}

Using Eq. (3), the relative importance of attributes can be calculated. Results are displayed in Table 3. The two most important attributes in our model are duration of the administrative process (25.6\%) and level

Table 2

Overview population size, PV market and geographical distribution of European PV project developers in our sample.

\begin{tabular}{|c|c|c|c|c|c|}
\hline & \multicolumn{2}{|l|}{ Population } & \multicolumn{3}{|l|}{ Sample } \\
\hline & $\begin{array}{l}\text { Size of the } \\
\text { Population }\end{array}$ & $\begin{array}{l}\text { PV Market Size (Installed PV capacity in } 2009 \text { (MWp)) } \\
\text { (Source: BFE, 2009; BFE (Hrsg.), 2010; Observ'ER, 2010) }\end{array}$ & $\begin{array}{l}\text { Country of Origin } \\
\text { (Headquarter) }\end{array}$ & $\begin{array}{l}\text { Target Country } \\
\text { (Investments) }\end{array}$ & $\begin{array}{l}\text { Familiarity with Country's } \\
\text { Energy Policy }\end{array}$ \\
\hline Germany & 150 & $6,019,000$ & $48.0 \%$ & $69.8 \%$ & $77.8 \%$ \\
\hline Italy & $40^{*}$ & 458,300 & $10.7 \%$ & $49.2 \%$ & $58.7 \%$ \\
\hline Spain & $60^{*}$ & $3,421,071$ & $17.3 \%$ & $57.1 \%$ & $71.4 \%$ \\
\hline France & $20^{*}$ & 103,902 & $4.0 \%$ & $27.0 \%$ & $36.5 \%$ \\
\hline Greece & $20^{*}$ & 18,500 & $2.7 \%$ & $30.2 \%$ & $42.9 \%$ \\
\hline Switzerland & $5^{*}$ & 72 & $5.3 \%$ & $14.3 \%$ & $12.7 \%$ \\
\hline Portugal & $10^{*}$ & 67,952 & $1.3 \%$ & $17.5 \%$ & $19.0 \%$ \\
\hline Austria & $10^{*}$ & 32,387 & $10.6 \%$ & $33.3 \%$ & $15.9 \%$ \\
\hline Benelux & $10^{*}$ & 152,685 & & & \\
\hline Czech Republic & $5^{*}$ & 54,674 & & & \\
\hline UK & $5^{*}$ & 22,510 & & & \\
\hline $\begin{array}{l}\text { Scandinavia (Denmark, } \\
\text { Sweden, Finland) }\end{array}$ & $5^{*}$ & 16,824 & & & \\
\hline Total & 340 & $10,367,847$ & $100 \%$ & $100 \%$ & $100 \%$ \\
\hline
\end{tabular}

* Own estimates, based on relative size of European PV markets. 


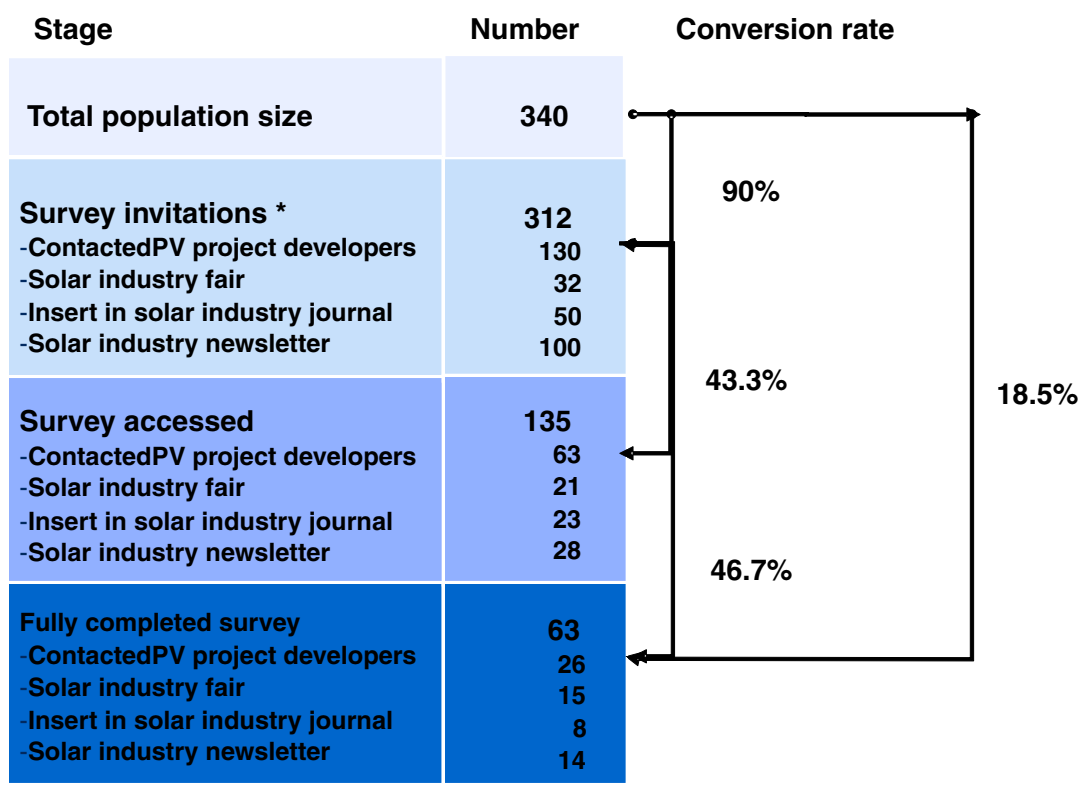

Fig. 3. Response funnel.

of the feed-in tariff (24.4\%). The existence of a cap and the number of PV policy changes are of medium importance with $18.7 \%$ and $17.7 \%$, respectively. The lowest importance (13.6\%) is attributed to the duration of the feed-in tariff.

\subsection{Part-worth utilities}

Average part-worth utilities, standard deviations, standard errors and t-values (ratio of mean to standard error) for each attribute level are displayed in Table 4. A t-test has been applied to test if part-worth utilities are statistically different from zero. The partworth utility analysis confirms that there is a positive monotonic relationship between attribute levels and utility, indicating that all else being equal, respondents consistently preferred choice alternatives with higher levels for each attribute. Standard deviations are generally low, with some exceptions for extreme attribute levels. The low distribution is also confirmed by an analysis of the correlations. Correlation coefficients of all respondents were close to 1 (0.95-0.99).

We used two measures to assess predictive accuracy of the HB model. First, a regression of the "Calibration Concept" ratings over the utility scores calculated by combining the information from the "Paired-Comparison" questions of the survey results in a R-squared of .744 , indicating a good fit. Second, we also checked the validity of the data by including three holdout tasks in our survey (cf. Table 5). Holdout tasks are constructed like the concepts in the calibration section of the survey but are not used for estimating the preferences (partworth utilities) of the respondents. The project developers' likelihood to invest in the respective policy frameworks can be compared with the model calculations of the investment likelihood. The analysis of the responses to the holdout task provides an indication of how well

Table 3

Relative importance of attributes.

\begin{tabular}{lll}
\hline Attribute & Average importance & Std. dev. \\
\hline Duration admin. process & $25.56 \%$ & 2.99035 \\
Feed-in tariff level & $24.37 \%$ & 2.81874 \\
Cap & $18.72 \%$ & 3.94464 \\
Solar policy changes & $17.74 \%$ & 3.55881 \\
Feed-in tariff duration & $13.61 \%$ & 3.43082 \\
\hline
\end{tabular}

the utility values estimated from the ACA/HB model (indirectly stated preferences) were able to predict the respondent's actual holdout choices (directly stated preferences). The average R-squared (from each individual's actual holdout ratings and SMRT simulation results (individual level)) is .778. The MAE (mean absolute error) (based on the individual holdout ratings and individual holdout predictions) is 12.

\subsection{Project developers' implicit willingness-to-accept certain policy risks}

In a next step, to facilitate interpretation of results and comparison of utilities across attributes, we calculated project developers' willingness-to-accept (WTA) certain policy risks using Eq. (5). Results are presented in Fig. 4 and briefly discussed below.

The choice experiments included three attribute levels regarding the existence of a cap: no cap, a cap that is going to be reached in 4 years (loose cap), and a cap that is going to be reached in 1 year (tight cap). The analysis shows that removing a loose (tight) cap will allow governments to attract the same level of investment at a feed-in tariff that is about $4.71(10.94) \mathrm{ct} / \mathrm{kWh}$ lower than in the base case. Regarding the policy risk duration of the administrative process, Fig. 4 shows that for every half-year increase in the duration of the administrative process, a government must pay project developers a feed-in tariff premium of $3.68 \mathrm{ct} / \mathrm{kWh}$ (all else being equal). With regard to policy stability, the study estimates that compared to full policy stability, in low risk conditions (one significant unexpected policy change in the last 5 years) the feed-in tariff needs to be $4.10 \mathrm{ct} / \mathrm{kWh}$ higher, whereas in high risk conditions (three significant unexpected policy changes in the last 5 years) a price premium of $10.28 \mathrm{ct} / \mathrm{kWh}$ will be required to maintain the same level of attractiveness. Finally, the duration of the support is also associated with a price tag. If the duration of a feed-in tariff is reduced from 25 to 15 years, the incentive needs to be 7.86 $\mathrm{ct} / \mathrm{kWh}$ higher as compensation.

\section{Conclusion}

\subsection{Summary and implications for policy makers}

Achieving energy policy objectives depends on whether public policy effectively influences investor behavior. In the specific case of feed-in tariffs for solar PV, there has been substantial policy 
Table 4

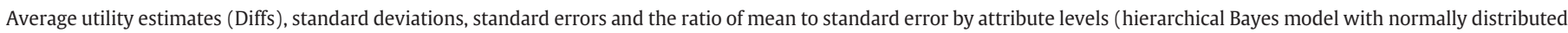
part-worth utilities).

\begin{tabular}{|c|c|c|c|c|c|}
\hline Attribute & Attribute level & $\begin{array}{l}\text { Mean part-worth } \\
\text { utility (Diffs) }\end{array}$ & $\begin{array}{l}\text { Standard } \\
\text { deviation }\end{array}$ & $\begin{array}{l}\text { Standard error } \\
\text { (St. Er.) }\end{array}$ & $\begin{array}{l}\text { Ratio of mean to standard error } \\
\text { (Mean/St. Er.) }\end{array}$ \\
\hline \multirow[t]{5}{*}{ Level of feed-in tariff } & $31 \mathrm{ct} / \mathrm{kWh}$ & 0 & - & - & - \\
\hline & $35 \mathrm{ct} / \mathrm{kWh}$ & $35.478^{* * *}$ & 4.703 & 0.593 & 59.873 \\
\hline & $38 \mathrm{ct} / \mathrm{kWh}$ & $62.420^{* * *}$ & 6.994 & 0.881 & 70.839 \\
\hline & $41 \mathrm{ct} / \mathrm{kWh}$ & $90.991^{* * *}$ & 11.273 & 1.420 & 64.068 \\
\hline & $45 \mathrm{ct} / \mathrm{kWh}$ & $122.009^{* * *}$ & 13.832 & 1.743 & 70.012 \\
\hline \multirow[t]{3}{*}{ Duration of feed-in tariff } & $15 \mathrm{y}$. of support & 0 & - & - & - \\
\hline & $20 \mathrm{y}$. of support & $37.541^{* * *}$ & 14.894 & 1.876 & 20.007 \\
\hline & $25 \mathrm{y}$. of support & $67.441^{* * *}$ & 16.982 & 2.1396 & 31.521 \\
\hline \multirow[t]{3}{*}{ Existence of a cap } & No cap & $93.560^{* * *}$ & 19.789 & 2.493 & 37.527 \\
\hline & Cap reached in $4 \mathrm{y}$. & $53.337^{* * *}$ & 17.149 & 2.161 & 24.687 \\
\hline & Cap reached in $1 \mathrm{y}$. & 0 & - & - & - \\
\hline \multirow[t]{5}{*}{ Duration of the administrative process } & $\begin{array}{l}\text { Administrative process of } 1- \\
2 \text { months }\end{array}$ & $128.271^{* * *}$ & 14.594 & 1.839 & 69.764 \\
\hline & $\begin{array}{l}\text { Administrative process of } 3- \\
6 \text { months }\end{array}$ & $96.144^{* * *}$ & 13.483 & 1.699 & 56.597 \\
\hline & $\begin{array}{l}\text { Administrative process of } 7- \\
12 \text { months }\end{array}$ & $65.677^{* * *}$ & 11.512 & 1.450 & 45.284 \\
\hline & $\begin{array}{l}\text { Administrative process of } 13- \\
18 \text { months }\end{array}$ & $33.418^{* * *}$ & 7.392 & 0.9313 & 35.884 \\
\hline & $\begin{array}{l}\text { Administrative process of } 19- \\
24 \text { months }\end{array}$ & 0 & - & - & - \\
\hline \multirow{3}{*}{$\begin{array}{l}\text { Significant unexpected policy changes in the } \\
\text { last } 5 \text { years }\end{array}$} & 0 policy changes & $88.719^{* * *}$ & 17.752 & 2.237 & 39.667 \\
\hline & 1 policy change & $53.473^{* * *}$ & 16.080 & 2.026 & 26.395 \\
\hline & 3 policy changes & 0 & - & - & - \\
\hline
\end{tabular}

*** Statistically different from zero at significance level of 0.01

experimentation and learning over recent years, but how investors react to certain policy attributes has been a black box until now. We have opened this black box by conducting a stated-preference survey among European project developers investing in solar energy across different countries.

Contributing to a growing research stream that uses choice experiments in energy economics, this study is one of the first empirical contributions that investigates the influence of renewable energy policies on project developers' decisions. Transferring a particular version of choice experiments that has proven successful in marketing research (adaptive conjoint analysis) to energy economics research, we determined the relative importance of certain policy risks and quantified the premium demanded by project developers to accept those risks. On a solid empirical basis, our research allows policy makers to assess the costs and benefits of reducing various elements of policy risk.

Overall, these findings confirm the importance of "non-economic" barriers - such as duration of the administrative process and political instability - to the deployment of renewable energy and thus demonstrate that risk matters in PV policy design. Project developers in our sample perceived the duration of the administrative process, followed

Table 5

Holdout tasks included in the survey.

\begin{tabular}{|c|c|c|c|}
\hline & Holdout 1 & Holdout 2 & Holdout 3 \\
\hline \multicolumn{4}{|l|}{ Policy framework } \\
\hline Duration admin. process (months) & $1-2$ & $19-24$ & $13-18$ \\
\hline Level of the FIT (ct/kWh) & 35 & 45 & 41 \\
\hline Cap & No cap & No cap & Cap reached in $1 \mathrm{y}$. \\
\hline Number of PV policy changes & 0 & 1 & 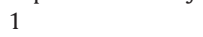 \\
\hline Duration of the FIT (years) & 20 & 20 & 25 \\
\hline \multicolumn{4}{|c|}{ Investing likelihood (given on a 0 to 100 scale) } \\
\hline $\begin{array}{l}\text { Mean of project developers' } \\
\text { likelihood }\end{array}$ & 87 & 72 & 38 \\
\hline SMRT Simulation & 79 & 65 & 43 \\
\hline
\end{tabular}

by the level of the feed-in tariff, as the most important attributes in the decision to invest in solar energy projects in a given country. We extended previous research by showing that a price tag can be attached to specific policy risks. This allows policy-makers to quantify and prioritize the influence of specific policy risks on investment behavior. This study shows that accelerating administrative process, removing a cap, increasing policy stability and/or increasing the duration of support are important ways in which policy-makers can increase their country's attractiveness for renewable energy investors. For each of those policy risks, our empirical results provide evidence for the level of risk premium that PV project developers will demand.

Governments can build on these findings to design policies that will be effective in attracting PV investment, while at the same time maintaining efficiency by providing an adequate compensation for policy risk. In particular, policy-makers should be aware that long administrative processes and, to a somewhat lesser extent, policy risks related to the existence of a cap and a substantial number of unexpected policy changes, have an attached cost that will need to be reflected in a higher level of feed-in tariffs to attract solar project developers.

\subsection{Limitations and further research}

Being one of the first of its kind in empirically investigating the reactions of international renewable energy project developers to policy risk with choice experiments, this study is subject to some limitations that provide starting points for further research.

First of all, our findings on the relative importance of different policy attributes in explaining the decision to invest in a given country is obviously limited to those attributes included in our experimental design. While the careful selection of attributes based on qualitative expert interviews gives us confidence that we have indeed picked relevant attributes for the choice situation under consideration, unobserved factors may play a role, particularly when it comes to transferring our findings to different contexts, such as renewable energy investment in emerging or developing countries. We would 


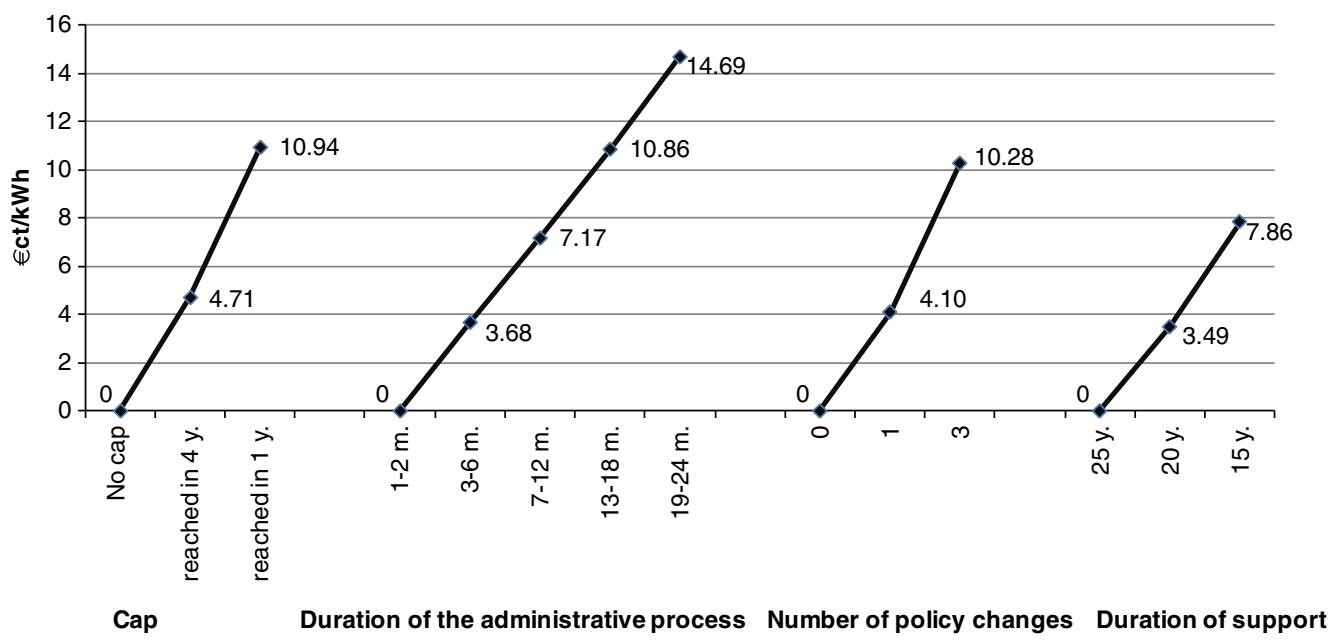

Fig. 4. Willingness-to-accept certain policy risks.

particularly highlight aspects of overall political stability, currency risk or legal security, which we did not include in our study because they are sufficiently similar within the European countries we investigated. Other unobserved factors include language, country size, personal contacts and social acceptance of the new technology (Wüstenhagen et al., 2007). We have decided not to include those factors in our choice experiments because they can only be influenced by policy-makers to a limited extent, but it seems plausible that they would also play a role. For example, all else being equal, a project developer may consider the fixed cost of starting operations in a large country like Spain more worthwhile than in a small country like $\mathrm{Cy}$ prus. These potential moderating factors should be kept in mind when interpreting our results.

The second limitation of our study is the size of our sample. Our sample consists of 63 early-stage European project developers conducting 25 choice tasks each, resulting in a total of 1575 observations. Out of the family of choice experimental methodologies, we have used $\mathrm{ACA} / \mathrm{HB}$ as it is particularly suitable for smaller sample sizes, and we are well within the range of minimum sample sizes recommended in the ACA literature. Nevertheless, further research should aim at validating our findings with larger sample sizes. It would be particularly interesting to investigate whether the assessment of renewable energy policy risk differs by types of investors (e.g., early-stage project developers vs. later-stage financiers, large vs. small firms) or across geographic regions (e.g., Europe vs. North America, Asia). We would note that when other researchers pick up on this suggestion, they should be conscious of the quality and consistency of the sample. The target population of our survey was a set of professional, real-world decision makers in an early-stage growth market. Thus, unlike surveys in more mature markets or with consumer or student samples, recruiting will inevitably remain a key challenge for follow-up research on renewable energy project developers.

A third limitation is that our results are based on stated preference data. We have consciously chosen a stated preference design to address some of the challenges of doing an analysis of revealed preferences in an early-stage growth market, such as the absence of sufficiently long time series and the difficulty in disentangling the importance of different policy attributes in explaining aggregate outcomes (such as installed capacity). However, future research should further explore the possibility of comparing our findings with revealed preference data, especially as feed-in tariffs continue to spread across more countries and longer time series become available.
A fourth limitation lies in our operationalization of policy stability. Our model and findings suggest that less policy changes are better, which is in line with previous research highlighting the importance of stable framework conditions for effective deployment policies for renewable energy, and this makes intuitive sense in cases where successful policies have been changed with negative consequences for renewable energy investment flows. On the other hand, there are situations in several countries where existing policies are clearly ineffective, such as Switzerland's feed-in tariff for solar energy, where an extremely tight cap led to a waiting list of 3000 projects immediately after the policy had been introduced. It would be a misinterpretation of our findings to suggest that such ineffective policies should be kept constant. Instead, the positive valuation of policy stability that we and others have identified seems to suggest that policymakers should conduct such changes with care and in a predictable manner and that it is a good idea to reduce the frequency of changes to a necessary minimum. Finally, there also is empirical evidence for non-linear reactions to policy stability, whereby announced policy changes initiate a boom-bust cycle. A prime example of this is the Spanish market for PV, which collapsed in 2009 due to policy changes, but this was preceded by a record year of installations in 2008 as international project developers rushed to Spain to implement their projects ahead of the expected changes. Our model and findings fail to explain such short-term cycles. Investigating longitudinal effects in policy implementation (Slemrod, 1992), as well as possible behavioral reactions to elements of policies (Hardisty et al. 2010), could be a promising avenue for further research.

\section{Acknowledgments}

This work was supported in part by the research project DISTRES (Project no. 031569). DISTRES (Distributed Renewable Energy Sources in the Mediterranean region) was financed by the European Commission under the International Cooperation (INCO) funding line of the 6th Framework Program for Research and Development (FP6). The authors wish to acknowledge the European Commission funding and the support of the DISTRES team. The authors further would like to thank Michaela Kohler for the collaboration during data collection. Participants of the 2009 International and European conferences of the International Association for Energy Economics (IAEE) as well as three anonymous reviewers and the editor are acknowledged for their valuable comments in improving the paper. All remaining errors are the sole responsibility of the authors. 


\section{Appendix A}

Descriptive statistics of European PV project developers in our sample.

\begin{tabular}{|c|c|c|}
\hline \multirow[t]{3}{*}{ Firm type } & $\begin{array}{l}\text { Specialized project } \\
\text { developer }\end{array}$ & $30.2 \%$ \\
\hline & $\begin{array}{l}\text { Vertically integrated } \\
\text { project developer }\end{array}$ & $50.8 \%$ \\
\hline & $\begin{array}{l}\text { Other (investors, } \\
\text { utilities, etc.) }\end{array}$ & $19.0 \%$ \\
\hline \multirow[t]{4}{*}{ Firm size } & 1-9 employees & $34.9 \%$ \\
\hline & 10-99 employees & $42.9 \%$ \\
\hline & 100-499 employees & $15.9 \%$ \\
\hline & >500 employees & $6.3 \%$ \\
\hline \multirow{5}{*}{$\begin{array}{l}\text { Firm's amount of annual PV project investment } \\
\text { (million Euros per year) }\end{array}$} & $1-9$ mio. $€$ & $20.6 \%$ \\
\hline & 10-99 mio. $€$ & $38.1 \%$ \\
\hline & 100-499 mio. € & $19.0 \%$ \\
\hline & $>500$ mio. $€$ & $3.2 \%$ \\
\hline & Not disclosed & $19.0 \%$ \\
\hline \multirow[t]{6}{*}{ Cumulative number of projects realized } & Total (entire sample) & 3800 \\
\hline & Median (per respondent) & 5 \\
\hline & 0 & $11.1 \%$ \\
\hline & $1-9$ & $49.2 \%$ \\
\hline & $10-99$ & $30.2 \%$ \\
\hline & $>100$ & $9.5 \%$ \\
\hline \multirow{3}{*}{$\begin{array}{l}\text { Average size of realized projects (installed } \\
\text { capacity) }\end{array}$} & $<100 \mathrm{~kW}$ & $33.3 \%$ \\
\hline & $100-500 \mathrm{~kW}$ & $23.8 \%$ \\
\hline & $>500 \mathrm{~kW}$ & $42.9 \%$ \\
\hline \multirow[t]{5}{*}{ Firm's focus of activities along the project cycle } & Planning phase only & $33 \%$ \\
\hline & Construction phase only & $6 \%$ \\
\hline & Operation phase only & $2 \%$ \\
\hline & Full project cycle & $56 \%$ \\
\hline & Other & $3 \%$ \\
\hline \multirow[t]{6}{*}{ Solar industry experience } & 1 year & $27.0 \%$ \\
\hline & $2-3$ years & $28.6 \%$ \\
\hline & $4-6$ years & $27.0 \%$ \\
\hline & $7-9$ years & $6.3 \%$ \\
\hline & $10-12$ years & $6.3 \%$ \\
\hline & $>12$ years & $4.8 \%$ \\
\hline
\end{tabular}

\section{References}

Ahn, J., Jeong, G., Kim, Y., 2008. A forecast of household ownership and use of alternative fuel vehicles: a multiple discrete-continuous choice approach. Energy Econ. 30, 2091-2104.

Amundsen, E.S., Mortensen, J.B., 2001. The Danish Green Certificate System: some simple analytical results. Energy Econ. 23, 489-509.

Anderson, N.H., 1970. Functional measurement and psychophysical judgment. Psychol. Rev. 153-170.

Backhaus, K., Erichson, B., Plinke, W., Weiber, R., 2006. Multivariate Analysemethoden. Eine anwendungsorientierte Einführung. : 2006Springer-Verlag, Berlin.

Banfi, S., Farsi, M., Filippini, M., Jakob, M., 2008. Willingness to pay for energy-saving measures in residential buildings. Energy Econ. 30, 503-516.

Ben-Akiva, M.E., Lerman, S.R., 1985. Discrete Choice Analysis: Theory and Application of Travel Demand. The MIT Press, Cambridge, Massachusetts.

Bergek, A., Jacobsson, S., 2010. Are tradable green certificates a cost-efficient policy driving technical change or a rent-generating machine? Lessons from Sweden 2003-2008. Energy Policy 38, 1255-1271.

Birol, F., 2003. World Energy Investment Outlook. International Energy Agency, Paris.

Böhringer, C., Löschel, A., Moslener, U., Rutherford, T.F., 2009. EU climate policy up to 2020: An economic impact assessment. Energy Economics 31, 295-305.

Boxall, P.C., Adamowicz, W.L., Swait, J., Williams, M., Louviere, J., 1996. A comparison of stated preference methods for environmental valuation. Ecol. Econ. 18, 243-253.

Breukers, S., Wolsink, M., 2007. Wind power implementation in changing institutional landscapes: an international comparison. Energy Policy 35, 2737-2750.

Bürer, M.J., Wüstenhagen, R., 2009. Which renewable energy policy is a venture capitalist's best friend? Empirical evidence from a survey of international cleantech investors. Energy Policy 37, 4997-5006.

Burkhalter, A., Känzig, J., Wüstenhagen, R., 2009. Kundenpräferenzen für leistungsrelevante Attribute von Stromprodukten. Zeitschrift für Energiewirtschaft 33, 161-172.

Butler, L., Neuhoff, K., 2008. Comparison of feed-in tariff, quota and auction mechanisms to support wind power development. Renew. Energy 33, 1854-1867.

Campoccia, A., Dusonchet, L., Telaretti, E., Zizzo, G., 2009. Comparative analysis of different supporting measures for the production of electrical energy by solar PV and Wind systems: Four representative European cases. Solar Energy 83, 287-297.

Casey, J.F., Kahn, J.R., Rivas, A.A.F., 2008. Willingness to accept compensation for the environmental risks of oil transport on the Amazon: a choice modeling experiment. Ecol. Econ. 67, 552-559.
Chattopadhyay, S., 2009. The random expenditure function approach to welfare in RUM: the case of hazardous waste clean-up. Resour. Energy Econ. 31, 58-74.

Clark-Murphy, M., Soutar, G.N., 2004. What individual investors value: some Australian evidence. J. Econ. Psychol. 25, 539-555.

De Jager, D., Rathmann, M., 2008. Policy instrument design to reduce financing costs in renewable energy technology projects. Ecofys, Utrecht.

Dinica, V., 2006. Support systems for the diffusion of renewable energy technologies an investor perspective. Energy Policy 34, 461-480.

Farber, S., Griner, B., 2000. Valuing watershed quality improvements using conjoint analysis. Ecol. Econ. 34, 63-76.

Flick, U., 1995. Qualitative Research. Theories, Methods, Applications in Psychology and Social Sciences (Qualitative Sozialforschung. : Theorien, Methoden, Anwendungen in Psychologie und Sozialwissenschaften)Rowohlt, Reinbeck/Hamburg.

Frondel, M., Ritter, N., Schmidt, C.M., 2008. Germany's solar cell promotion: dark clouds on the horizon. Energy Policy 36, 4198-4204.

Glenn, H., Wattage, P., Mardle, S., Rensburg, T.V., Grehan, A., Foley, N., 2010. Marine protected areas - substantiating their worth. Mar. Policy 34, 421-430.

Green, P.E., Srinivasan, V., 1990. Conjoint analysis in marketing: new developments with implications for research and practice. J. Mark. 54, 3-19.

Gross, R., Blyth, W., Heptonstall, P., 2010. Risks, revenues and investment in electricity generation: why policy needs to look beyond costs. Energy Econ. 32, 796-804.

Hardisty, D.J., Johnson, E.J., Weber, E.U., 2010. A Dirty Word or a Dirty World? Attribute Framing, Political Affiliation, and Query Theory. Psychological Science 21 (1), 86-92.

Hensher, D.A., 1994. Stated preferences analysis of travel choices - the state of practice. Transportation 21, 107-133.

Hensher, D.A., 2010. Hypothetical bias, choice experiments and willingness to pay. Transportation Research Part B: Methodological 44, 735-752.

Howell, J., 2009. CBC/HB for Beginners, research paper series. Sawtooth Software, Inc. Sequim, WA.

Intergovernmental Panel on Climate Change, 2011. Special report on renewable energy sources and climate change mitigation, Chaper 11: Policy, Financing and Implementation. IPCC, Geneva.

Jacobsson, S., Lauber, V., 2006. The politics and policy of energy system transformation - explaining the German diffusion of renewable energy technology. Energy Policy 34, 256-276.

Jacobsson, S., Bergek, A., Finon, D., Lauber, V., Mitchell, C., Toke, D., Verbruggen, A., 2009 EU renewable energy support policy: faith or facts? Energy Policy 37, 2143-2146.

Jensen, S.G., Skytte, K., 2002. Interactions between the power and green certificate markets. Energy Policy 30, 425-435.

Kruskal, J.B., 1965. Analysis of factorial experiments by estimating monotone transformations of the data. J. R. Stat. Soc. 251-263 Serie B.

Kühn, I., 1999. New competition-based support schemes for electricity generation from renewable energy sources. In: GEE, V.C. (Ed.), 1st Austrian-Czech-German Conference: Energy Market Liberalisation in Central and Eastern Europe, Prague, pp. 114-119.

Lancaster, K.J., 1966. A new approach to consumer theory. J. Polit. Econ. 74, 132-157. Langniss, O., 1999. Financing Renewable Energy Systems. DRL, Stuttgart.

Lenk, P.J., DeSarbo, W.S., Green, P.E., Young, M.R., 1996. Hierarchical Bayes conjoint analysis: recovery of partworth heterogeneity from reduced experimental designs. Mark. Sci. 15, 173-191.

Lenz, S., Pfaffenberger, W., 1999. Stromhandel mit erneuerbaren Energieträgern mit einem Quotenmodell, 63th Conference of the German Society of Physics (DPG), Heidelberg.

Lipp, J., 2007. Lessons for effective renewable electricity policy from Denmark, Germany and the United Kingdom. Energy Policy 35, 5481-5495.

Lohrke, F.T., Holloway, B.B., Woolley, T.W., 2010. Conjoint analysis in entrepreneurship research: a review and research agenda. Organ. Res. Methods 13.

Luce, D., Turkey, J., 1964. Simultaneous conjoint measurement: a new type of fundamental measurement. J. Math. Psychol. 1, 1-27.

Lüthi, S., 2010. Effective deployment of photovoltaics in the Mediterranean countries: balancing policy risk and return. Solar Energy 84, 1059-1071.

Mansky, C., 1977. The structure of random utility models. Theory Decis. 8, 229-254

Masini, A., Menichetti, E., 2012. The impact of behavioural factors in the renewable energy investment decision making process: Conceptual framework and empirical findings. Energy Policy 40, 28-38.

McFadden, D., 1986. The choice theory approach to market research. Mark. Sci. 5, 275.

Menanteau, P., Finon, D., Lamy, M.-L., 2003. Prices versus quantities: choosing policies for promoting the development of renewable energy. Energy Policy 31, 799-812.

Mitchell, C., Bauknecht, D., Connor, P.M., 2006. Effectiveness through risk reduction: comparison of the renewable obligation in England and Wales and the feed-in system in Germany. Energy Policy 34, 297-305.

Moxnes, E., 2004. Estimating customer utility of energy efficiency standards for refrigerators. J. Econ. Psychol. 25, 707-724.

Nadaï, A., 2007. "Planning", "siting" and the local acceptance of wind power: some lessons from the French case. Energy Policy 35, 2715-2726.

Netzer, O., Toubia, T., Bradlow, E.T., Dahan, E., Evgeniou, T., Feinberg, F.M., Feit, E.M., Hui, S.K., Johnson, J., Liechty, J.C., Orlin, J.B., Rao, V.R., 2008. Beyond conjoint analysis: advances in preference measurement. Mark. Lett. 19, 337-354.

OECD/IEA, 2008. Deploying Renewables: Principles for Effective Policies, Paris.

Orme, B., 2001. Assessing the Monetary Value of Attribute Levels with Conjoint Analysis: Warnings and Suggestions. Sawtooth Software, Inc., Sequim, WA.

Orme, B., 2007a. Software for Hierarchical Bayes Estimation for CBC Data, CBC/HB v4 Sawtooth Software Inc., Sequim, WA.

Orme, B., 2007b. Which conjoint method should I use? Research Paper Series. Sawtooth Software Inc, Sequim, WA.

Orme, B., 2010a. Getting Started with Conjoint Analysis: Strategies for Product Design and Product Research, Second Edition. Research Publisher Madison, WI. 
SSI Web Documentation: SSI Web v7.0 - Software for Web Interviewing and Conjoint Analysis (Updated 28 April 2010). In: Orme, B. (Ed.), Sawtooth Software Inc.

Palmer, K., Burtraw, D., 2005. Cost-effectiveness of renewable electricity policies. Energy Econ. 27, 873-894.

Paris, R., 2010. Solarsquare AG.

Poortinga, W., Steg, L., Vlek, C., Wiersma, G., 2003. Household preferences for energysaving measures: a conjoint analysis. J. Econ. Psychol. 24, 49-64.

Priem, R.L., Harrison, D.A., 1994. Exploring strategic judgment: methods for testing the assumptions of prescriptive contingency theories. Strateg. Manag. J. 15, 311-324.

Ragwitz, M., Held, A., Resch, G., Haas, R., Faber, T., Huber, C., Morthorst, P.E., Jensen, S. Coenraads, R., Voogt, M., Reece, G., Konstantinaviciute, I., Heyder, B., 2007. OPTRES Assessment and optimisation of renewable energy support schemes in the European electricity market. EU IEE project funded by DG TREN, Karlsruhe and Vienna. .

Rickerson, W., Grace, R.C., 2007. The Debate of Fixed Price Incentives for Renewable Electricity in Europe and the United States: Fallout and Future Directions. Heinrich Böll Foundation North America, Washington, DC.

Ringel, M., 2006. Fostering the use of renewable energies in the European Union: the race between feed-in tariffs and green certificates. Renew. Energy 31, 1-17.

Roe, B., Boyle, K.J., Teisl, M.F., 1996. Using conjoint analysis to derive estimates of compensating variation. J. Environ. Econ. Manag. 31, 145-159.

Ropenus, S., Jensen, S.G., 2009. Support schemes and vertical integration - who skims the cream? Energy Policy 37, 1104-1115.

Rossi, P.E., Allenby, G.M., 2003. Bayesian statistics and marketing. Mark. Sci. 22, 304-328.

Rowlands, I.H., 2005. Envisaging feed-in tariffs for solar photovoltaic electricity: European lessons for Canada. Renewable Sustainable Energy Rev. 9, 51-68.

Sarasin, 2009. Solarwirtschaft - grüne Erholung in Sicht: Technologien, Märkte und Unternehmen im Vergleich. Bank Sarasin \& Cie AG, Basel.

Sawtooth Software, 2007. The ACA/Web v6.0, Technical Paper Series. Sawtooth Software Inc, Sequim, WA.

Slemrod, J., 1992. Do Taxes Matter? Lessons from the 1980's. The American Economic Review 82 (2), 250-256.
Toke, D., Breukers, S., Wolsink, M., 2008. Wind power deployment outcomes: how can we account for the differences? Renewable Sustainable Energy Rev. 12, 1129-1147.

Train, K., 2009. Discrete Choice Methods with Simulation, 2nd ed. Cambridge University Press, New York.

Train, K., Wilson, W.W., 2008. Estimation on stated-preference experiments constructed from revealed-preference choices. Transp. Res. B: Methodol. 42, 191-203.

Usher, E, 2008. Global investment in the renewable energy sector. In: Hohmeyer, 0. Trittin, T. (Eds.), IPCC Scoping Meeting on Renewable Energy Sources, Lübeck, pp. 147-154.

Venditti, P., Peterson, D., Siegel, M., 2007. Evaluating financial deals using a holistic decision modeling approach. Sawtooth Conference, Santa Rosa, California, pp. 23-42.

Verbruggen, A., 2004. Tradable green certificates in Flanders (Belgium). Energy Policy $32,165-176$.

Verhaegen, K. Meeus, L., Belmans, R., 2009. Towards an international tradable green certificate system - the challenging example of Belgium. Renewable Sustainable Energy Rev. 13, 208-215.

Wilcox, R., 1999. Efficient fee structures for mutual funds. Sawtooth Software Conference, Sequim, WA, pp. 71-97.

Wiser, R., Pickle, S., 1998. Financing investments in renewable energy: the impacts of policy design. Renewable Sustainable Energy Rev. 2, 361-386.

Wüstenhagen, R., Bilharz, M., 2006. Green energy market development in Germany: effective public policy and emerging customer demand. Energy Policy 34, 1681-1696.

Wüstenhagen, R., Menichetti, E., 2012. Strategic choices for renewable energy investment: Conceptual framework and opportunities for further research. Energy Policy 40, 1-10.

Wüstenhagen, R., Wolsink, M., Bürer, M.J., 2007. Social acceptance of renewable energy innovation: an introduction to the concept. Energy Policy 35, 2683-2691. 